\title{
Analisis Manajemen Lembaga Tahfidz Dalam Meningkatkan Kualitas Bacaan Al-Qur'an Mahasisiwi Iiq Jakarta
}

\author{
Sri Widyastri ${ }^{1}$, Isman Iskandar ${ }^{2}$ \\ email: widi@iiq.ac.id, isman@iiq.ac.id,
}

\begin{abstract}
This paper reveals and collaborates descriptively on the management of the Qur'anic tahfidzh institute at the Jakarta Institute of Sciences (IIQ). One of the formal institutions in the field of religious education is rife in the community. Although there have been many formal institutions in the field of religion, especially the Qur'an, which have been successful with a large number of students and good administration, there are also many institutions that have been deflated, especially in urban areas. However, the institution of tahfizh at IIQ Jakarta is increasingly in demand because it shows the achievements of the tahfizh of the Qur'an at national and international levels. This data collection is carried out through document studies, interviews and observations with analytical techniques: 1) Data Reduction, 2) Data Display, 3) Comparative Analysis, and 4) Drawing Conclusions. To maintain the objectivity of the data, a number of appropriate data validity testing techniques are carried out including the credibility test,testing transfer, dataand data triangulation. The results of this study indicate that in the planning of tahsin Al-Qur'an in LTQQ has been well structured because LTQQ formulated it by giving matriculation at the beginning of the semester, fostering tahsin outside of lecture hours and tahsin exams before completing final studies. In each class, students are divided into groups, consisting of 7-10 people and guided by instructors who are appointed by the leadership of IIQ on the proposal of LTQQ and then endorsed by the Chancellor. Evaluating the learning of tahsin Al-Qur'an is done once a week and every time a memorization is made. Evaluation is also carried out at the end of the semester with assessment criteria including: craft, reading fluency, truth of makhraj and tajwid and murattal cleanness. Then this evaluation was reported by each instructor to the LTQQ. Students who have exceeded the specified maqra ' limit, have true makhraj and tajwidnya, and are good at heart, are allowed to take the tahsin exam and are given grades.
\end{abstract}

Keywords: Management, Institution, Tahfidz and Al-Qur'an Reading

\begin{abstract}
ABSTRAK
Tulisan ini mengungkap dan mengolaborasi secara deskriptip manajemen lembaga tahfidzh Al-Qur'an di Institut Ilmu Al-Qur'an (IIQ) Jakarta. Salah satu lembaga formal di bidang pendidikan agama yang marak di masyarakat. Meskipun sudah banyak lembaga formal di bidang agama khususnya AlQur'an yang sukses dengan jumlah murid yang banyak dan administrasi yang
\end{abstract}

\footnotetext{
${ }^{1}$ Mahasiswa Doktor Pascasarjana UIN Syarif Hidayatullah Jakarta

2 Dosen Institut Ilmu Al-Qur'an (IIQ) Jakarta
} 
bagus, namun juga masih banyak lembaga yang kembang kempis apalagi di tengah perkotaan. Akan tetapi lembaga tahfizh yang ada di IIQ Jakarta ini semakin diminati sebab menunjukkan prestasi tahfizh Al-Qur'an di tingkat nasional dan Internasional. Pengumpulan data ini dilakukan melalui studi dokumen, wawancara dan observasi dengan teknik analisis: 1) Reduksi Data, 2) Display Data, 3) Analisis Perbandingan, serta 4) Penarikan Kesimpulan. Untuk menjaga objektifitas data maka dilakukan beberapa teknik penguji keabsahan data yang sesuai meliputi uji kredibilitas, pengujian transferadibily, dan triangulasi data. Hasil penelitian ini menunjukkan bahwa dalam perencanaan tahsin Al-Qur'an di LTQQ sudah terstruktur dengan baik karena LTQQ merumuskannya dengan pemberian matrikulasi di awal semester, pembinaan tahsin di luar jam kuliah dan ujian tahsin sebelum menyelesaikan studi akhir. Dalam setiap kelas mahasiswa dibagi dalam beberapa kelompok, yang terdiri 7-10 orang dan dibimbing lansung instruktur yang diangkat oleh pimpinan IIQ atas usulan LTQQ kemudian disahkan oleh Rektor. Pengevaluasian pembelajaran tahsin AlQur'an dilakukan setiap seminggu sekali dan setiap melakukan setoran hafalan. Pengevaluasian juga dilakukan diakhir semester dengan kriteria penilaian meliputi: kerajinan, kelancaran bacaan, kebenaran makhraj dan tajwid serta kebagusan murattal. Kemudian pengevaluasian ini dilaporkan oleh masingmasing instruktur kepda LTQQ. Mahasiswa yang sudah melampaui batas maqra' yang ditentukan, benar makhraj dan tajwidnya, serta bagus murattalnya diperbolehkan mengikuti ujian tahsin dan diberikan nilai.

Kata Kunci: Manajemen, Lembaga, Tahfidz dan Bacaan Al-Qur'an

\section{PENDAHULUAN}

Secara moral, umat Islam memiliki kewajiban untuk memajukan lembaga-lembaga pendidikan Islam dengan menerapkan manajemen yang baik sesuai dengan moralitas Al-Quran untuk mewujudkan lembaga pendidikan Islam yang maju menuju Islam yang berkemajuan. Lembaga pendidikan yang baik dan mendukung terselenggaranya suatu pendidikan amat dibutuhkan dan turut berpengaruh terhadap pencapaian tujuan pendidikan yang diinginkan. ${ }^{3}$ Untuk mewujudkan tujuan pendidikan yang diinginkan maka perlu perencanaan yang terstruktur atau managemen. Sebagai salah satu tuntutan zaman, manajemen sangat diperlukan untuk menopang pelaksanaan pendidikan.

Berbicara tentang manajemen lembaga khususnya lembaga-lembaga pendidikan Islam sangatlah kompleks. Sebab, Kemajuan sains dan teknologi berdampak serius pada kehidupan manusia. Efek negatif dari globalisasi dan krisis lingkungan hidup harus dihadapi oleh umat

${ }^{3}$ Arif Amhari, "Lembaga Pendidikan Penghafal Al-Quran: Studi Perbandingan Pesantren Tahfidl Sulaymaniyah Turki Dan Pesantren Tahfidl Indonesia," KURIOSITAS: Media Komunikasi Sosial Keagamaan 8, no. 2 (2015): 53. 
Muslim. Pendidikan Islam harus mampu membangun generasi Muslim yang tangguh melalui pendidikan Islam yang bermutu dan berkualitas, pendidikan yang mampu "menguasai"—bukan "dikuasai"- ilmu pengetahuan dan teknologi. ${ }^{4}$

Kemajuan sains tersebut harus diiringi dengan peningkatan manajemen yang baik agar lembaga-lembaga pendidikan Islam bermutu dan mampu berkompetitif di era modern ini. Dengan berbagai muatan dan modifikasinya, lembaga-lembaga tersebut menjadi institusi andalan umat Islam dalam proses pembelajaran dan pendidikan Islam. Hal ini membuktikan bahwa lembaga penddikan Islam dalam dunia Islam mampu bertahan dan menyesuaikan diri di tengah arus modernisasi pendidikan yang melanda sebagian besar dunia Islam.

Jika aktivitas lembaga dilaksanakan sesuai dengan prinsip-prinsip manajemen, maka cita profesional dalam lembaga akan terwujud dalam kehidupan masyarakat. Karena manusia akan selalu mengalami perkembangan peradababan. Sejalan dengan perkembangan peradaban manusia yang semakin maju dan teknologi semakin canggih, kebutuhan hidup suatu masyarakat yang semakin hari semakin sulit, ditambah dengan kesenjangan hidup antara kaya dan miskin serta semakin kompleksnya persoalan yang dihadapi. ${ }^{5}$

Untuk mengatasi hal diatas, diperlukan pembentukan karakter salah satunya adalah dengan tahfizh Al-Qur'an. Beberapa penelitian telah menunjukkan bahwa para penghafal AlQur'an memilki karakter yang bermoral meskipun derasnya arus globalisasi tak yang kian menerpa manusia.

Sebagaimana dalam hasil penelitian Ayu Desrani dkk menunjukkan bahwa "Di Madrasah Aliyah Negeri (MAN) 3 Palembang melakukan penerapan pendidikan karakter di asrama melalui bahasa arab melalui bebera kegiatan kajian kitab, muhadoroh, al-barzanji, tahfidz al-qur'an, membaca surah yasin, bimbel malam, dan pentas seni. Adapun karakter yang dapat dihasilkan dari kegiatan- kegiatan tersebut adalah religious, bertanggung jawab, disiplin, percaya diri, kreatif, komunikatif, rasa ingin tahu, sopan dan santun, sabar, ikhlas, rendah hati, mandiri, jujur, menghargai, kreatif dan inovatif ${ }^{\prime 6}$

\footnotetext{
${ }^{4}$ Aisyah Tidjani, "Manajemen Lembaga Pendidikan Islam Menghadapi Tantangan Globalisasi," Reflektika 12, no. 1 (2017): 96-133.

${ }^{5}$ Isman Iskandar, Baharuddin Ali, and Mahmuddin Mahmuddin, "Manajemen Dakwah Ma'Had Al-Sunnah Kabupaten Sidrap,” Jurnal Diskursus Islam 5, no. 1 (May 1, 2017): 43-66.

${ }^{6}$ Ayu Desrani, Kamila Adnan, Mar'atun Naziroh, Pendidikan Karakter Dalam Program Asrama Bahasa Arab Menghadapi Era Revolusi Industri 4.0 Di Man 3 Palembang, Prosiding Konferensi Pendidikan Nasional, (2020): 305-17.
} 
Melalui kegiatan ekstrakurikuler tahfidz al qur'an siswa mampu mengembangkan dirinya, mengasah bakat yang terpendam pada dirinya, dan lebih mencintai al qur'an untuk dihafalkan dengan lantunan bacaan yang merdu untuk didengarkan, dan mampu menjadi pribadi yang memiliki karakter baik dan percaya diri. Hasil penelitian ini dapat digunakan sebagai wawasan kepada pihak sekolah untuk selalu memberikan motivasi pada peserta didiknya untuk aktif dalam mengikuti kegitan esktrakurikuler tahfidz al qur'an sehingga nantinya hasil dari kegiatan tersebut mampu mencetak kader muda dan lulusan terbaik dari sekolah SD Muhammadiyah 1 Trenggalek. $^{7}$

Karakter yang dibentuk pembinaan melalui kegiatan Ekstrakurikuler Tahfidz yaitu, karakter religius, karakter cinta membaca dan menghafal Al Qur'an, sopan santun. ${ }^{8}$

Oleh karena itu, dalam lembaga -lembaga pendidikan Islam agar mampu bersaing di dunia era modern ini perlu peningkatan manajemen yang baik. Karena, lembaga pendidikan Islam menjadi institusi andalan umat Islam.

Tulisan ini mengungkap dan mengolaborasi secara deskriptip manajemen lembaga tahfidzh Al-Qur'an di Institut Ilmu Al-Qur'an (IIQ) Jakarta. Salah satu lembaga formal di bidang pendidikan agama yang marak di masyarakat. Meskipun sudah banyak lembaga formal d bidang agama khususnya Al-Qur'an yang sukses dengan jumlah murid yang banyak dan administrasi yang bagus, namun juga masih banyak lembaga yang kembang kempis apalagi di tengah perkotaan. Akan tetapi lembaga tahfizh yang ada di IIQ jakarta ini semakin diminati selalu karena menunjukkan prestasi tahfizh Al-Qur'an di tingkat nasional dan Internasional.

\section{PEMBAHASAN DAN TEMUAN PENELITIAN}

1. Manajemen Kelembagaan

Dalam Kamus Besar Bahasa Indonesia, manajemen diartikan sebagai penggunaan sumber daya secara efektif untuk mencapai sasaran. ${ }^{9}$ Manajemen berasal dari kata to manage yang artinya mengatur. Pengaturan yang dilakukan melalaui proses dan diatur berdasarkan urutan dari fungsi-fungsi menajemen dan juga manajemen merupakan suatu proses untuk mewujudkan

\footnotetext{
${ }^{7}$ Rizka Ayu Fitrianingsih, Nugrananda Janattaka, Analisis Penguatan Pendidikan Karakter Peserta Didik Melalui Kegiatan Ekstrakurikuler Tahfidz Al Qur'an Pada Siswa Sd Muhammadiyah 1 Trenggalek, Jurnal Pendidikan Dasar Nusantara, Volume 5, Nomor 2, Januari 2020.

${ }^{8}$ Zulkifli, Wirdanengsih, Pendidikan Karakter melalui Kegiatan Ekstrakurikuler Tahfidz di SMA Negeri 5 Jurnal Sikola: Jurnal Kajian Pendidikan dan Pembelajaran VOL. 1 NO. 3 MARET 2020

${ }^{9}$ Departemen Pendidikan dan Kebudayaan, Kamus Besar Bahasa Indonesia, Edisi II, Jakarta: Balai Pustaka, 1986, hal. 716.
} 
tujuan yang diinginkan. ${ }^{10}$ Pada intinya manajemen berusaha mengatur sumber daya secara efektif untuk mencapai tujuan yang ditetapkan.

Dalam bahasa Arab, istilah manajemen diartikan al-niz\}a>m dan al-tanz\}im yang merupakan suatu tempat untuk menyimpan segala sesuatu dan penempatan segala sesuatu pada tempatnya. ${ }^{11}$ Pengertian tersebut dalam skala aktivitas juga dapat diartikan sebagai aktivitas menerbitkan, mengatur, dan berpikir yang dilakukan oleh seseorang, sehingga ia mampu mengemukakan, menata, dan merapikan segala sesuatu yang ada disekitarnya, mengetahui prinsip-prinsipnya serta menjadikan hidup selaras dan serasi dengan yang lainnya. ${ }^{12}$

Sedangkan secara terminologi terdapat banyak definisi oleh para ahli, di antaranya adalah Robert Kreitner memaknai manajemen dalam bukunya sebagai berikut: Management is a the procces of working with and through other to achieve organizational objectives in a changing environment. Central to this process is the effective and efficient use of limited resources. ${ }^{13}$

Manajemen adalah proses kerja dengan dan melalui orang lain untuk mencapai tujuan organisasi dalam lingkungan yang berubah. Proses ini berpusat pada penggunaan secara efektif dan efesien terhadap sumber daya yang terbatas. Sedangkan G.R. Terry mendefinisikan Manajemen sebagai berikut: Manajemen adalah suatu proses atau kerangka kerja, yang melibatkan bimbingan atau pengarahan suatu kelompok orang-orang kearah tujuan-tujuan organisasional atau maksud-maksud yang nyata. ${ }^{14}$

Pada hakikatnya, manajemen adalah kemampuan dan keterampilan seseorang untuk merencanakan, mengatur, dan mengelola serta mengawasi jalannya suatu kegiatan atau program, sehingga secara optimal dapat mencapai tujuan yang diinginkan dengan tepat waktu dan tepat sasaran. ${ }^{15}$ Manajemen dapat dijabarkan sebagai berikut:

a. Ketatalaksanaan proses penggunaan sumber daya secara efektif untuk mencapai sasaran tertentu. hal. 1.

${ }^{10}$ H. Malayu S.P Hasibuan, Manajemen: Dasar, Pengertian, dan Masalah, Jakarta: PT Bumi Aksara, 2007,

${ }^{11}$ Ahmad Warson Munawwir, Kamus al-Munawwir Arab-Indonesia, Cet. XIV; Surabaya: Pustaka Progressif, 1997, hal. 1435. 2009, hal. 9.

${ }^{12}$ M. Munir dan Wahyu Ilahi, Manajemen Dakwah, Jakarta: Kencana Prenada Media Group, Vol. 02 Tahun

${ }^{13}$ Robert Kreitner, Mangement $4^{\text {th }}$ Edition, Boston: Hougton Mifflin Company, 1989, hal. 9.

${ }^{14}$ George, R. Terry, Leslie W. Rue, Principles of Management. Terj G.A Ticaulu, Dasar-Dasar Manajemen, Cet. IX; Jakarta: PT. Bumi Aksara, 2005, hal. 1.

${ }^{15}$ H.Malayu S.P Hasibuan, Manajemen: Dasar, Pengertian, dan Masalah, Jakarta: PT Bumi Aksara, 2007, hal. 1. 
b. Kemampuan atau keterampilan untuk memperoleh suatu hasil dalam rangka pencapaian tujuan melalui kegiatan-kegiatan orang lain.

c. Seluruh pertemuan menggerakkan sekelompok orang dan menggerakkan fasilitas dalam suatu usaha kerja sama untuk mencapai tujuan tertentu. ${ }^{16}$

\section{Realitas Lembaga Tahfizh Dan Qira'at Al-Qur'an (LTQQ)}

a. Sejarah Institut Ilmu Al-Qur'an

Atas gagasan Prof KH Ibrahim Hosen, LML yang juga sebagai Rektor pertama IIQ Jakarta saat itu. Institut ilmu Al-Qur'an didirikan pada tanggal 1 April 1977 Masehi. ${ }^{17}$ Pada mulanya IIQ membuka Program Magister khusus untuk wanita dengan dukungan penuh dari seluruh gubernur di seluruh Indonesia guna memenuhi seluruh tenaga khusus di berbagai propinsi dan dipersiapkan pula sebagai tenaga pengajar pada program Strata satu (S1). Setelah meluluskan dua angkatan IIQ membuka program S1 tahun 1982 dan membuka kembali Program S2 tahun 1998. IIQ terletak di Jalan Ir. H. Juanda No 70, Ciputat, Kota Tangerang Selatan, Provinsi Banten.

b. Visi, Misi dan Tujuan Institut Ilmu Al-Qur’an (IIQ) Jakarta

Sebagai acuan dalam menjalankan aktivitas sehari-hari, perjalanan dan perkembangan IIQ Jakarta tidak terlepas dari visi, misi dan tujuan yang telah disusun. Berikut ini adalah Visi Institut Ilmu Al-Qur'an (IIQ) Jakarta: "Menjadi Pusat Studi dan Riset Al-Qur'an Terbaik dan Terdepan di Dunia Tahun 2028"18

Sedangkan Misinya yaitu dapat di lihat sebagai berikut: 1) Menyelenggarakan pendidikan dan pengajaran tingkat perguruan tinggi yang mengintegrasikan system pendidikan nasional dan pesantren yang mewajibkan menghafal Al-Qur'an, serta berdaya saing. 2) Menyelenggarakan penelitian untuk memperdalam dan mengembangkan ilmu-ilmu Al-Qur'an sesuai kebutuhan masyarakat. 3) Melaksanakan praktik dan pengabdian kepada masyarakat untuk mengembangkan keterampilan bidang ilmu Al-Qur'an dank e-Islaman. 4) Menyelenggarakan

\footnotetext{
2009, hal. 12.

${ }^{17}$ Tim Penulis, Pedoman Akademik Program S1 (IIQ) Jakarta Tahun 2014-2019, Jakarta: IIQ Press, 2014, hal. 7-8 dan Website resmi IIQ Jakarta: https//iiq.ac.id. Bandingkan dengan tulisan Nur izzah, Metode Maisura Terhadap Tingkat Bacaan Al-Qur'an Mahasiswa IIQ,Jakarta: LPPI IIQ, 2014, hal 39.

${ }^{18}$ Tim Penulis, Statuta Institut Ilmu Al-Qur'an (IIQ) Jakarta, Kebayoran Baru: Di Terbitkan oleh Yayasan Institut Ilmu Al-Qur'an (YIIQ) Jakarta, 2016, hal 16.
}

${ }^{16}$ M. Munir dan Wahyu Ilahi, Manajemen Dakwah, Jakarta: Kencana Prenada Media Group, Vol. 02 Tahun 
kerjasama dengan berbagai lembaga dan institusi, baik local, nasional, regional dan internasional di bidang Al-Qur'an dan ilmu ke-Islaman, dan 5) Melaksanakan tata kelola (good governance) ${ }^{19}$

Dari visi misi dan tujuan diatas dapat disimpulkan bahwa IIQ Jakarta merupakan perguruan tinggi keagamaan Islam swasta yang sangat memperhatikan nilai-nilai ke Islaman dalam pengembangan masyarakat. Hal tersebut dapat dilihat dari misi, visi dan tujuannya yang ingin maju dan terkemuka bersama masyarakat religius yang membumikan Al-Qur'an.

\section{c. Lembaga Tahfizh dan Qira'at Al-Qur'an (LTQQ)}

Lembaga Tahfizh dan Qira'at Al-Qur'an (LTQQ) adalah lembaga yang bertanggung jawab menyelenggarakan pelayanan administrasi, pembinaan, pembibitan dan pengkaderan yang berkaitan dengan tahfizh, tahsin dan qira'at Al-Qur'an. Tahfizh AlQur'an adalah kegiatan menghafal Al-Qur'an secara bertahap yang dibimbing oleh instruktur sesuai dengan program yang ditentukan. Tahsinut Tilawah adalah memperbaiki atau membaguskan bacaan Al-Qur'an sesuai dengan kaidah ilmu Tajwid. Qira'at AlQur'an adalah kajian tentang tata cara membaca Al-Qur'an sesuai dengan kaidah-kaidah Ilmu Qira' at yang diakui kesahihannya. ${ }^{20}$

Penguatan peran dan fungsi LTQQ tidak terbatas hanya pada penyelenggaraan Musabaqah Tilawatil Qur'an dan sejenisnya diberbagai tingkatan untuk mahasiswa IIQ. LTQQ mempunyai tugas dan fungsi pembinaan dan pengembangan pendidikan non formal dan informal di bidang Al-Qur'an dan pelatihan Qori dan Qoriah, Hafidz dan Hafidzah, dan sejenisnya diberbagai tingkatan. Selain itu mengoptimalkan peran instansi terkait dan Pemerintah Daerah dalam mendukung program LTQQ Maka dari itu, untuk meningkat kualitas bacaan Al-Qur'an, LTQQ IIQ Jakarta perlu meningkatkan peran secara lebih maksimal dan optimal.

Peran LTQQ diantaranya: 1. Mengadakan seleksi MTQ/STQ tingkat IIQ, hal ini dimaksudkan untuk menyaring dan menemukan bibit-bibit Qori' dan Qori'ah, Hafidz dan Hafidzah yang benar-benar mempunyai potensi dan bakat alam, sehingga bisa tercipta

\footnotetext{
${ }^{19}$ Tim Penulis, Statuta Institut Ilmu Al-Qur'an (IIQ) Jakarta, Kebayoran Baru: Di terbitkan oleh Yayasan Institut Ilmu Al-Qur'an (YIIQ) Jakarta, 2016, hal 16-17.

${ }^{20}$ Romlah Widayati, Kaidah Qira'at 7, Jakarta: IIQ Press, 2012, hal. 8.
} 
seorang Qori' dan Qor'iah Hafidz dan Hafidzah yang handal. 2. Mengadakan pembinaan terkhusus pada perbaikan kualitas bacaan Al-Qur'an agar lebih kompetitif dan menemukan bibit Qori' dan Qori'ah yang memang unggulan dan berbakat. Pelatihan dan pembinaan tersebut harus bersifat continue, berkelanjutan, dan terprogram. Pelatihan tidak hanya dilakukan untuk menghadapi MTQ Nasional atau Internasional saja, akan tetapi harus dilakukan secara berkala dan efektif 3. Mengadakan pelatihan Dewan Hakim tingkat IIQ untuk pembekalan mahasiswa akhir sebelum Praktik lansung di dunia MTQ dan praktik di masyarakat. Agar dalam menilai bisa lebih Profesional dan jauh dari unsur subyektifitas, sehingga diperoleh peserta yang benar-benar terbaik. 4. Mengadakan pelatihan dan pembinaan bagi Qori dan Qori'ah, Hafidz dan Hafidzah terbaik di tingkat Institut 5.. Mengirim para peserta terbaik dari IIQ untuk melakukan Pelatihan dengan LPTQ DKI Jakarta. Hal ini dimaksudkan untuk menambah ilmu pengetahuan Tilawah dan menambah wacana tentang Tilawatil Qur'an. 7. Memperhatikan kesejahteraan peserta ketika akan mengikuti MTQ tingkat Nasional. Peserta harus diperhatikan secara khusus, selain dari pelatihan, peserta harus diperhatikan dari segi materi. Uang transport dan uang saku peserta harus lebih di perhatikan, dan memberikan bonus atau reward manakala peserta dari IIQ bisa menjadi juara MTQ di tingkat Nasional. Hal ini bisa memacu semangat dan perjuangan para peserta agar lebih maksimal saat tampil di mimbar Tilawah di Level Nasional.

\section{ANALISIS MANAJEMEN LEMBAGA TAHFIDZ DAN QIRA'AT AL-QUR'AN IIQ JAKARTA}

\section{Planning}

Dalam hal perencanaan awal, LTQQ menyediakan silabus yang di rangkum dari metode maisuro seperti yang disebutkan di awal yaitu mengadakan pelatihan metode maisuro, akan tetapi dalam pelatihan ini isi metode maisuro belum disampaikan secara keseluruhan akan tetapi LTQQ menyampaikan hanya point-point nya saja. Kemudian di kelas perkuliahan diadakan tahsin per minggu. Sejalan dengan itu, bahwa pembinaan intensif yang meliputi pembinaan tahsin tilawah diwajibkan bagi seluruh mahasiswa baru. 
Sebelum mengikuti kuliah semester I yang dilaksanakan selama 20 hari di Pesantren Takhassus IIQ Jakarta. ${ }^{21}$ Kemudian pelaksanaan matrikulasi diharapkan mahasiswa sudah fasih membaca Al-Qur'an agar tidak terbawa dengan dialek ke daerahan masingmasing. Hal ini sangat menunjang mahasiswa untuk menghafal Al-Qur'an dan mendapatkan nilai A atau setara dengan $80 .{ }^{22}$ LTQQ sudah menjamin bahwa mahasiswa yang mengikuti program matrikulasi rata-rata sudah bisa membaca Al-Qur'an dengan baik sesuai dengan standar minimum menghafal Al-Qur'an. Hal ini juga dibuktikan dengan penelitian Nur Izzah ${ }^{23}$ bahwa perbedaan bacaan mahasiswa sebelum mengikuti matrikulasi dan setelah mengikuti materikulasi sangat signifikan rata-rata yang usdah mengikuti kegiatan matrukulasi bacaanya sudah sangat bagus tinggal disempurnakan apabila ada yang terlupakan.

Dalam pelaksanaan matrikulasi dan output yang dihasilkan LTQQ, adalah sesuatu yang sangat bagus karena mengutamakan kefasihan membaca AlQur'an dan hal ini sangat jarang kita temui pada lembaga-lembaga tahfidz lainnya yang hanya mengutamakan kecepatan menghafal dalam tempo sesingkat-singkatnya akan tetapi masih dipertanyakan dalam kefasihannya. LTQQ selalu mengutamakan kualitas bacaan Al-Qur'an walaupun mahasiswa dari nol namun LTQQ melakukan pembinaan terus menerus sehingga membuahkan hasil yang maksimal juga.

Banyak sekali faedah (manfaat) dari membaca Al-Qur'an, di antaranya: Al-Qur'an membimbing menuju ke jalan yang lurus. Allah SWT berfirman dalam Surat al-Isro' ayat 9

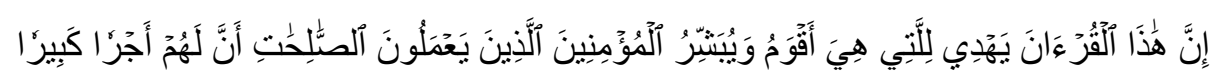

“Sesungguhnya Al-Qur'an ini memberikan petunjuk kepada) jalan (yang lebih lurus) lebih adil dan lebih besar (dan memberi kabar gembira kepada orang-orang mukmin yang mengerjakan amal saleh bahwa bagi mereka ada pahala yang besar".

Nabi SAW mengingatkan agar seorang penghafal Al-Qur'an memberikan perhatian yang besar atas pemeliharaan hafalannya karena hafalan yang telah dikuasai dapat terlupakan yang telah ada dalam memori tidak terjamin akan hafal selama-lamanya

${ }^{21}$ Data dari Hayati, Ciputat, Jumat 13 Oktober 2018 Pukul 10.00 WIB

${ }^{22}$ Wawancara dengan mutmainnah, Ciputat, Jumat 13 Oktober 2018

${ }^{23}$ Nur Izzah, Metode Maisura Terhadap Tingkat Bacaan Al-Qur'an Mahasiswa IIQ Jakarta, LPPI IIQ Jakarta: Ciputat, 2014, hal 17. 
karena hafal yang dapat bertahan paling lama 12 jam. Psikologi pendidikan membagi ada tiga tahapan dalam proses penyampaian sebuah informasi dalam memori dan pengungkapannya yaitu memasukkan informasi, menyimpan dan mengingat memanggil kembali penyimpangan.

Dengan demikian metode tahfidz dan takrir yang dilaksanakan oleh LTQQ sangat relevan dengan pesan Nabi SAW agar para penghafal Al-Qur'an senantiasa mengulang hafalannya agar hafalannya tidak lepas dari ingatan sebagaimana unta yang mudah lepas dari ikatannya jika tidak di ikat dengan kuat.

Sebagaimana kita ketahui bahwa dalam tahapan ini yakni ingatan terbagi menjadi dua tahap ingatan jangka pendek dan dan ingatan jangka panjang, informasi yang masuk pada ingatan jangka pendek hanya transit sejenak untuk memasuki ingatan jangka panjang uang bisa hilang kegagalan dalam penyimpanan atau salah satu dari tiga tahap ini disebut lupa. ${ }^{24}$ Kegagalan dalam penyimpanan di mana hafalan tetap ada tetapi mengalami kekaburan dapat disebabkan oleh membiarkan hafalan tidak terpakai kembali. Pemeliharaan hafalan Al-Qur'an terbagi menjadi dua macam yang pertama bagi yang belum selesai 30 juz dan bagi yang telah selesai $30 \mathrm{Juz}$ bagian belum selesai atau belum khatam terdapat beberapa cara dalam merawat hafalan.

Manajemen Silabus LTQQ sudah sangat bagus apalagi di setiap semester diterapkan metode takrir untuk membantu mahasiswa mengingat kembali hafalan yang sudah disetorkan pada tahap awal. Akan tetapi alangkah baiknya jika LTQQ memfasilitasi Instruktur dan para Mahasiswa untuk mengadakan study tour agar tidak terjadi kejenuhan dalam menghafal Al-Qur'an.

\section{Organizing}

Dalam hal struktur organisasi, LTQQ memiliki seorang ketua, sekretaris, dan seorang staf. Adapun semua staf pengajar termasuk instruktur tahfidz juga merupakan inti dari LTQQ. Karena mereka selain instruktur tahfidz atau menerima setoran hafalan juga sebagai instruktur tahsin yang harus memperbaiki bacaan mahasiswa. Tugas dari seorang instruktur selain memantau, menyimak, dan memperbaiki bacaan juga harus melaporkan setiap akhir semester. Lembaga Tahfidz dan Qira'at Al-Qur'an di Institut Ilmu Al-Qur'an Jakarta dalam membagi pekerjaan dan penugasan setiap aktivitas lembaga Tahfidz dan

\footnotetext{
${ }^{24}$ Abdurrahman Abdul Khaliq, Cara Cerdas Hafal Al-Qur'an. Solo: Penerbit Aqwam, 2007, hal. 34.
} 
Qira'at Al-Qur'an diketuai oleh Hj Mutmainnah bendahara oleh Istiqomah dan sekretaris oleh hayati.

Menurut Mutmainnah masih kekurangan instruktur dibandingkan dengan mahasiswa yang semakin banyak ${ }^{25}$ instruktur yang masih terbilang sedikit dan juga menurut hayati LTQQ butuh staff untuk melayani semua mahasiswa dari fakultas Tarbiyah Ushuluddin Syariah dan juga menurut Muthmainnah bahwa ada beberapa staf termasuk dirinya menjabat sebagai dosen dengan tugas tambahan. Sejauh ini hampir 70\% kewajiban sudah terlaksana $30 \%$ nya masih belum bisa terlaksana karena dirinya juga sebagai dosen mengajar di setiap kelas dan juga staf yang lain. Istiqomah juga merangkap sebagai wakil direktris asrama Pesantren takhassus sehingga bannya belum bisa maksimal karena tugas yang diberikan kepadanya dari kampus.

Seorang Instruktur harus peka terhadap perkembangan proses menghafal mahasiswa, baik yang berkaitan dengan perbaikan bacaan Al-Qur'an, menghafal, rutinitas setoran tambahan dan takrir, ataupun yang berkaitan dengan psikolgi penghafal. Jadi seorang instruktur bukan hanya memberikan motivasi, tapi juga yang lebih penting adalah mengendalikan, sehingga penghafal tidal merasa dipaksa oleh semangat yang diluar batas kemampuannya. ${ }^{26}$

Berdasarkan pengamatan penulis terhadap peranan instruktur atau pembimbing tahfidz untuk memberikan pengaruh kepada mahasiswa dalam pembelajaran Tahfidz AlQur'an di Institut Ilmu Al-Qur'an Jakarta sangat besar sekali dalam menjaga dan mengembangkan minat menghafal mahasiswa.

Hal ini dapat dilihat pada setiap hari sebelum jam belajar dimulai dan juga sore setelah belajar selesai para instruktur terlibat langsung dalam kegiatan tasmi di samping itu menurut pengamatan penulis, instruktur-instruktur atau pembimbing juga tidak keberatan menerima mahasiswa yang mau menyetorkan hafalan nya walaupun sudah waktu pulang

Selanjutnya dalam hal sebagai penjaga kemurniaan Al-Qur'an dan setiap instruktur Al-Qur'an sepenuhnya dapat melaksanakan perannya secara maksimal karena dari 29

\footnotetext{
${ }^{25}$ Wawancara dengan Mutmainnah, Ciputat, Selasa 18 September 2018 Pukul 09.00 WIB

${ }^{26}$ Ahsin, W. Al-Hafidz, Bimbingan Praktis Menghafal Al-Qur'an, Jakarta, PT Rosdakarya, 2017, hal. 75-76
} 
orang sangat tepat untuk diangkat sebagai instruktur tahsin dan tahfidz Al-Qur'an disebabkan kompetensi mereka terhadap ilmu tajwid Al-Qur'an sangat berkompeten.

Hal ini dibuktikan dengan pengamatan penulis yang menemukan adanya instruktur yang menegur kesalahan makhraj huruf dan kesalahan tajwid mahasiswa yang sedang melakukan setoran hafalan kepadanya. Penulis juga mengamati instruktur setiap kelompok karena itu menurut pendapat penulis sebaiknya instruktur diberikan bentuk apresiasi yang layak karena sudah memberikan pelayanan yang baik kepada mahasiswa.

Instruktur tahsin diharapkan dapat langsung dan lebih teliti memperhatikan mahasiswa yang ada dalam bimbingannya mengingat pembelajaran tahsin Al-Qur'an diulang-ulang setiap mahasiswa secara berkesinambungan jika tidak tentu materi yang sudah diberikan dan implementasi ayat akan menjadi lupa bila tidak diulang-ulang.

Sehubungan dengan hal ini Zaki Zamani dan Muhammad Syukron Maksum ${ }^{27}$ mengatakan menambah hafalan adalah penting tetapi yang mengulang atau murojaah hafalan juga tidak kalah pentingnya karena tanpa mengulang hafalan yang sudah didapat usaha kita dalam menghafal ayat-ayat sebelumnya akan sia-sia.

Mengenai pengangkatan instruktur tahfidz, Alim Al-Qahir ${ }^{28}$ mengatakan pentingnya keberadaan seorang Syekh, anda tidak akan mampu menghafal sedikitpun tanpa adanya seorang Syekh atau Anda tidak akan mungkin bisa menguasai hukum-hukum tajwid jika tidak ada seorangpun yang mendengarkan bacaan atau membenarkannya

Mengenai jumlah staf yang hanya 2 orang dan Instruktur 29 orang, sangat tidak mendukung jalannya proses pembelajaran. Mengapa? Karena LTQQ melayani semua mahasiswa dari 3 Fakultas yang jumlah mahasiswanya lebih dari seribu orang. Apalagi instruktur yang harus melayani 30 orang dalam sehari sangat tidak efektif karena tugas instruktur adalah menyimak hafalan dan mengoreksi bacaan yang salah. Apabila instruktur tidak jeli maka hal ini membuat mahasiswa akan melakukan kesalahan terus menerus. Perlu adanya perekrutan staf LTQQ dan calon instruktur agar pelayanan di LTQQ maksimal.

\section{Actuating}

\footnotetext{
${ }^{27}$ Zaki Zamami dan Muhammd Syukron, Pentingnya Murajaah, http//iwiqhed.co.id, diakses pada Minggu 12 September 2018.

${ }^{28}$ Alim Al-Qahir, Urgensi Berguru kepada Guru, https/alhmdulillah.co.id, diakses pada senin 13 September 2018 Pukul 12.00 WIB
} 
Sejauh ini lebih dari 70\% sudah berjalan, sisanya karena keterbatasan waktu dari instruktur. Karena ada instruktur yang merangkap. Contoh Mutmainnah selaku ketua LTQQ Juga merangkap sebagai instruktur tahsin, tahfidz, dan dosen di kampus dan juga di asrama. Sehingga dalam pelaksanaan tahsin tidak berjalan lancar. Istiqomah selaku Sekretaris LTQQ juga merangkap sekretaris Direktur asrama, instruktur tafidz, tahsin. Sehingga tugasnya tidak terlaksana maksimal.

Seharusnya seorang karyawan harus loyal dalam organisasi. Seorang anggota yang memiliki loyalitas terhadap organisasinya memiliki kesadaran pribadi untuk memanfaatkan semua potensi yang ada dalam dirinya demi kemajuan organisasi. Loyalitas dapat diartikan tekad dan kesanggupan menaati, melaksanakan, dan mengamalkan sesuatu dengan disertai penuh kesadaran dan tanggung jawab. Tekad dan kesanggupan tersebut harus dibuktikan dalam sikap dan tingkah laku sehari-hari serta dalam pelaksanaan tugas. Loyalitas anggota terhadap organisasi memiliki makna kesediaan seseorang untuk melenggangkan hubungannya dengan organisasi, kalau perlu mengorbankan kepentingan pribadinya tanpa mengharapkan apapun.

Loyalitas anggota memegang peranan krusial dalam jalannya organisasi. Tata aturan yang sempurna, program kerja yang brilian sangat dibutuhkan dalam organisasi. Nasib organisasi tersebut ke depannya akan ditentukan oleh tingkat loyalitas anggotanya. Apabila anggota merasa "malas" maka untuk merealisasikan program kerja organisasi akan terasa sangat sulit. Tidak lain alasan dari itu semua adalah karena kurangnya rasa memiliki oleh setiap anggotanya. Ya, dari sini penulis kembali menyatakan bahwa loyalitas amat sangat berarti bagi eksistensi sebuah organisasi. Loyalitas ibarat ruh bagi organisasi. Dan tentunya, tanpa ruh, sebuah organisasi tak akan mampu bernafas lebih lama, yang akhirnya berakibat dan berujung pada 'matinya' organisasi tersebut.

\section{Controlling}

Menurut Mutmainnah bahwa semua instruktur menyampaikan laporan kepada Ketua LTQQ Laporan yang telah disampaikan dari instruktur masing-masing akan dinilai, sejauh mana perkembangan bacaan mahasiswa. ${ }^{29}$ Apabila ada mahasiswa yang bermasalah dari sisi bacaan dan kerajinan maka pihak LTQQ akan mengadakan rapat untuk membahas mahasiswa tersebut. Sejauh ini rapat yang sudah dilaksanakan oleh

${ }^{29}$ Wawancara dengan Mutmainnah, Ciputat, Rabu 12 September 2018, pukul 09.00 WIB 
pihak LTQQ yaitu rapat di awal sebelum perkuliahan, rapat pertengahan dan rapat akhir sebulan sebelum UAS. Berdasarkan hasil wawancara, dokumentasi dan observasi, controlling yang dilakukan oleh LTQQ masih sangat kurang karena ketua LTQQ harus menunggu laporan dari para instruktur. Dari pernyataan tersebut, dapat ditarik kesimpulan bahwa pengawasan yang ada di LTQQ sudah terlaksana dengan baik sesuai dengan SOP IIQ Jakarta.

\section{KESIMPULAN}

Manajemen LTQQ yaitu Planning, Organizing, Actuating dan Controlling yang akan diuraikan sebagai berikut:

1. Planning

Dalam perencanaan tahsin Al-Qur'an di LTQQ sudah terstruktur dengan baik karena LTQQ merumuskannya dengan pemberian matrikulasi di awal semester, pembinaan tahsin di luar jam kuliah dan ujian tahsin sebelum menyelesaikan studi akhir. Dalam seteiap kelas mahasiswa dibagi dalam beberapa kelompok, yang terdiri 7-10 orang dan dibimbing lansung instruktur yang diangkat oleh pimpinan IIQ atas usulan LTQQ kemudian disahkan oleh Rektor.

Dalam perencanaan pembelajaran, instruktur-instruktur tahsin belum membuat rancangan/modul pembelajaran secara tertulis dengan alasan tidak menggunakan modul tetapi menggunakan buku maisura sebagai panduan tahsin. Instruktur-instruktur tahsin hanya memberikan maqra' yang harus dibacakan kepada mahasiswa pada saat dikelas dan diikuti oleh mahasiswa lalu dinta membacakan dari satu mahasiswa ke mahasiswa berikutnya atau estafet ayat.

2. Organizing

Dalam pengaturan pelaksanaan fungsi, tugas dan kewajiban semua staff dan instruktur masih belum terlaksana secara maksimal. Hal ini dikarenakan masih ada instruktur yang merangkap sebagai dosen, sebagai wakil direktur asrama. Sehingga pelayanan kepada mahasiswa sangat kurang. Banyaknya mahasiswa non aktif belum melaksanakan ujian tahsin karena waktu dari instruktur kepada mahasiswa sangat sedikit.

3. Actuating

Pelaksanaan tahsin Al-Qur'an di LTQQ sangat dipacu oleh kebijakan-kebijakan ketua LTQQ dan didukung oleHH tim yang solid baik dari tenaga administrasi LTQQ maupun dari instruktur-instruktur pembimbing. Akan tetapi pada kenyataan tidak ada kebijakan dari LTQQ terhadap mahasiswa yang sudah lulus studi tetapi belum ujian tahsin. Instruktur-instruktur tahsin telah mengenalkan metode-metode lain kepada mahasiswa dalam pembelajaran tahsin. Dalam pelaksanaannya, pembelajaran tahsin Al-Qur'an tidak 
mengurangi prestasi akademik mahasiswa tetapi sebaliknya meningkatkan prestasi dalam dunia MTQ.

Peran instruktur dan LTQQ dalam meingkatkan dan menjaga kualitas bacaan AlQur'an mahasiswa sangat besar sekali. Hanya ada sebagian kecil instruktur dan staf LTQQ yang merangkap sebagai dosen yang perlu di pertimbangkan sehingga pelayanan kurang maksimal dalam membimbing tahsin dan tahfidz.

4. Controlling

Pengevaluasian pembelajaran tahsin Al-Qur'an dilakukan setiap seminggu sekali dan setiap melakukan setoran hafalan. Pengevaluasian juga dilakukan diakhir semester dengan kriteria penilaian meliputi: kerajinan, kelancaran bacaan, kebenaran makhraj dan tajwid serta kebagusan murattal. Kemudian pengevaluasian ini dilaporkan oleh masingmasing instruktur kepda LTQQ. Mahasiswa yang sudah melampaui batas maqra' yang ditentukan, benar makhraj dan tajwidnya, serta bagus murattalnya diperbolehkan mengikuti ujian tahsin dan diberikan nilai.

\section{DAFTAR PUSTAKA}

Departemen Pendidikan dan Kebudayaan, Kamus Besar Bahasa Indonesia, Edisi II, Jakarta: Balai Pustaka, 1986

S.P Hasibuan, Malayu, Manajemen: Dasar, Pengertian, dan Masalah, Jakarta: PT Bumi Aksara, 2007

Munawwir, Warson, AhmadKamus al-Munawwir Arab-Indonesia, Cet. XIV; Surabaya: Pustaka Progressif, 1997

Ilahi, Wahyu, Munir, M Manajemen Dakwah, Jakarta: Kencana Prenada Media Group, Vol. 02 Tahun 2009

Kreitner, Robert, Mangement $4{ }^{\text {th }}$ Edition, Boston: Hougton Mifflin Company, 1989

George, R. Terry, Leslie W. Rue, Principles of Management. Terj G.A Ticaulu, Dasar-Dasar Manajemen, Cet. IX; Jakarta: PT. Bumi Aksara, 2005

H.Malayu S.P Hasibuan, Manajemen: Dasar, Pengertian, dan Masalah, Jakarta: PT Bumi Aksara, 2007

Tim Penulis, Pedoman Akademik Program S1 (IIQ) Jakarta Tahun 2014-2019, Jakarta: IIQ Press, 2014

Tim Penulis, Statuta Institut Ilmu Al-Qur'an (IIQ) Jakarta, Kebayoran Baru: Di Terbitkan oleh Yayasan Institut Ilmu Al-Qur'an (YIIQ) Jakarta, 2016

Tim Penulis, Statuta Institut Ilmu Al-Qur'an (IIQ) Jakarta, Kebayoran Baru: Di terbitkan oleh Yayasan Institut Ilmu Al-Qur'an (YIIQ) Jakarta, 2016

Widayati, Romlah, Kaidah Qira'at 7, Jakarta: IIQ Press, 2012 
Izzah, Nur, Metode Maisura Terhadap Tingkat Bacaan Al-Qur'an Mahasiswa IIQ Jakarta, LPPI IIQ Jakarta: Ciputat, 2014

Tim Penulis, Pedoman Akademik Program S1 (IIQ) Jakarta Tahun 2014-2019, Jakarta: IIQ Press, 2014

Abdurrahman Abdul Khaliq, Cara Cerdas Hafal Al-Qur'an. Solo: Penerbit Aqwam, 2007

Hafidz, Ahsin, Bimbingan Praktis Menghafal Al-Qur'an, Jakarta, PT Rosdakarya, 2017

Zamami, Zakidan Muhammd Syukron, Pentingnya Murajaah, http//iwiqhed.co.id, diakses pada Minggu 12 September 2018.

Al-Qahir, AlimUrgensi Berguru kepada Guru, https/alhmdulillah.co.id, diakses pada senin 13 September 2018 Pukul 12.00 WIB.

Amhari, Arif, Lembaga Pendidikan Penghafal Al-Quran: Studi Perbandingan Pesantren Tahfidl Sulaymaniyah Turki Dan Pesantren Tahfidl Indonesia," KURIOSITAS: Media Komunikasi Sosial Keagamaan 8, no. 2 (2015): 53.

Ayu Fitrianingsih, Rizka, Janattaka, Nugrananda, Analisis Penguatan Pendidikan Karakter Peserta Didik Melalui Kegiatan Ekstrakurikuler Tahfidz Al Qur'an Pada Siswa Sd Muhammadiyah 1 Trenggalek, Jurnal Pendidikan Dasar Nusantara, Volume 5, Nomor 2, Januari 2020, DOI: https://doi.org/10.29407/jpdn.v5i2.13372

Desrani, Ayu, Adnan, Kamalia, Naziroh, Mar'atun, Pendidikan Karakter Dalam Program Asrama Bahasa Arab Menghadapi Era Revolusi Industri 4.0 Di Man 3 Palembang, Prosiding Konferensi Pendidikan Nasional, (2020): 305-17.

Iskandar, Isman, Baharuddin Ali, and Mahmuddin Mahmuddin, "Manajemen Dakwah Ma'Had AlSunnah Kabupaten Sidrap,” Jurnal Diskursus Islam 5, no. 1 (May 1, 2017): 43-66.

Tidjani, Aisyah"Manajemen Lembaga Pendidikan Islam Menghadapi Tantangan Globalisasi," Reflektika 12, no. 1 (2017): 96-133.

Wirdanengsih, Zulkifli, Pendidikan Karakter melalui Kegiatan Ekstrakurikuler Tahfidz di SMA Negeri 5 Jurnal Sikola: Jurnal Kajian Pendidikan dan Pembelajaran Vol. 1 No. 3 Maret 2020, DOI: https://doi.org/10.24036/sikola.v1i3.23 